University of New Hampshire

University of New Hampshire Scholars' Repository

1995

\title{
An Ice-Core-Based, Late Holocene History for the Transantarctic Mountains, Antarctica
}

\author{
Paul A. Mayewski \\ University of New Hampshire - Main Campus \\ W. Berry Lyons \\ University of Alabama - Tuscaloosa \\ Gregory A. Zielinski \\ University of New Hampshire - Main Campus \\ Mark S. Twickler \\ University of New Hampshire - Main Campus \\ Sallie I. Whitlow \\ University of New Hampshire - Main Campus
}

See next page for additional authors

Follow this and additional works at: https://scholars.unh.edu/earthsci_facpub

\section{Recommended Citation}

Mayewski, P. A., Lyons, W. B., Zielinski, G., Twickler, M., Whitlow, S., Dibb, J., Grootes, P., Taylor, K., Whung, P.-Y., Fosberry, L., Wake, C. and Welch, K. (1995) An Ice-Core-Based, Late Holocene History for the Transantarctic Mountains, Antarctica, in Contributions to Antarctic Research IV (eds D. H. Elliot and G. L. Blaisdell), American Geophysical Union, Washington, D. C.. doi: 10.1002/9781118668207.ch4

This Book Chapter is brought to you for free and open access by the Earth Sciences at University of New Hampshire Scholars' Repository. It has been accepted for inclusion in Earth Sciences Scholarship by an authorized administrator of University of New Hampshire Scholars' Repository. For more information, please contact Scholarly.Communication@unh.edu. 


\section{Authors}

Paul A. Mayewski, W. Berry Lyons, Gregory A. Zielinski, Mark S. Twickler, Sallie I. Whitlow, Jack E. Dibb, P Grootes, K Taylor, P-Y Whung, L Fosberry, Cameron P. Wake, and K Welch 


\title{
AN ICE-CORE-BASED, LATE HOLOCENE HISTORY FOR THE TRANSANTARCTIC MOUNTAINS, ANTARCTICA
}

\author{
P. A. Mayewski, ${ }^{1}$ W. B. Lyons, ${ }^{1,2}$ G. Zielinski, ${ }^{1}$ M. Twickler, ${ }^{1}$ S. Whitlow, ${ }^{1}$ J. Dibb,${ }^{1}$ \\ P. Grootes ${ }^{3}$ K. Taylor, ${ }^{4}$ P.-Y. Whung, ${ }^{5}$ L. Fosberry, ${ }^{1}$ C. Wake, ${ }^{1}$ and K. Welch ${ }^{1}$
}

Ice core records (major anions and cations, MSA, oxygen isotopes and particles) developed from two shallow ( $200 \mathrm{~m}$ depth) sites in the Transantarctic Mountains provide documentation of much of the Holocene paleoenvironmental history of this region. From the more southerly site, Dominion Range, an 7000-year-long record reveals change in the influence of tropospheric transport to the region. At this site, milder conditions and increased tropospheric inflow prior to $\sim 1500 \mathrm{yr}$ BP are characterized by increased seasalt (ss), terrestrial and marine biogenic inputs. Increased persistence and/or extent of polar stratospheric clouds accompanying generally cooler conditions characterize much of the period since $\sim 1500$ yr BP. From the more northerly site, Newall Glacier, the dramatic influence of the retreat of grounded ice from McMurdo Sound dated at $<6600 \mathrm{yr}$ BP [Denton et al., 1989] dominates much of the ice core record. This regional environmental change is documented by massive influxes to the core site of evaporitic salts from areas exposed during low lake level stands. During the past $\sim 150$ yr, both Dominion Range and Newall Glacier appear to be experiencing an overall increase in the exposure of ice-free terrain.

\section{INTRODUCTION}

The vast extent of the Antarctic Ice Sheet and its setting amidst rimming oceans contrast markedly with the geography of the Arctic. The effect that this dramatic difference has had on the paleoclimatic histories of these two polar regions remains an intriguing and increasingly important scientific issue. Paleoclimate studies in the Arctic reveal a variety of climatic changes that vary in duration from decades to centuries (e.g., Little Ice Age, Medieval Warm Pe-

\footnotetext{
${ }^{1}$ Glacier Research Group, Institute for the Study of Earth, Oceans and Space, University of New Hampshire, Durham.

${ }^{2}$ Hydrology/Hydrogeology Program, Mackay School of Mines, University of Nevada, Reno.

${ }^{3}$ Quaternary Isotope Laboratory, University of Washington, Seattle.

${ }^{4}$ Water Resources Center, Desert Research Institute, University and Community College System of Nevada, Reno.

${ }^{5}$ Rosenstiel School of Marine and Atmospheric Sciences, University of Miami, Florida.
}

riod, Younger Dryas) to millennia (e.g., Climatic Optimum, glacial maxima). In the Arctic there is abundant evidence for regional differences in the onset, duration and termination of several climatic events [Grove, 1988]. While one might assume that the Antarctic would reveal a less dynamic climate history because of the internal momentum inherent in the massive volumes of ice and ocean, details of its paleoclimatic history remain unresolved. Most paleoclimatic investigation in the Antarctic has focused on deep sea sediment records and on ice core records from the interior portions of the ice sheet (e.g., Byrd, Vostok, Dome C). These records have primarily characterized major paleoclimate events (glacialinterglacial cycles) and do not yet appear to reveal notable differences from site to site. It is, however, within the late Wisconsin and Holocene portion of the climate record that the temporal and spatial sensitivity of climate change can best be tested. Not only was there dramatic change during these periods, but the records of these younger events are relatively well preserved.

Glacial geologic investigations suggest that massive changes in the extent of grounded ice character- 


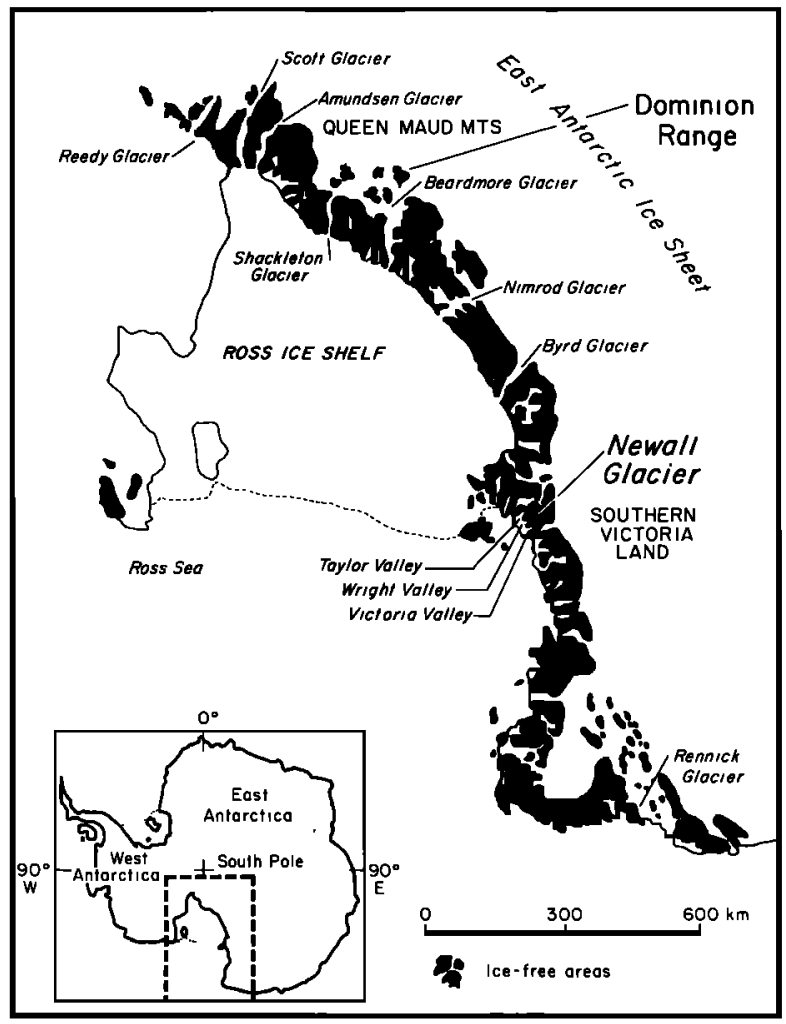

Fig. 1. Location map.

ized the Ross Sea Embayment during the late Wisconsin and early Holocene [Denton et al., 1989]. In this paper we present paleoclimate records from two sites in the Ross Sea Embayment (Figure 1). The ice core records recovered from these two sites differ from other Antarctic ice core records because they were retrieved from localized accumulation basins within the Transantarctic Mountains rather than from interior portions of the ice sheet. The Dominion Range site is largely dominated by: (1) the interaction of katabatic winds, which flow off the polar plateau and funnel down outlet glaciers on either side of this range, and (2) air masses that move from West Antarctica inland toward the plateau from the Ross Ice Shelf. The Newall Glacier site is dominated by: (1) katabatic winds that flow off the polar plateau and funnel down through the ice-free valleys of Southern Victoria Land, and (2) circulation directed southward around Northern Victoria Land. Both sites experience upslope winds that allow valley bottom air to reach the coring sites. At the Newall Glacier site, this provides sufficient loft to allow local dusts and evaporitically produced salts to be deposited at the core site; at the Dominion Range site, nearby valleys are ice-filled, and ice-free exposures are more limited in extent. These sites effectively serve as "islands" that capture environmental signatures monitoring local- to regional-scale change in circulation dynamics and atmospheric source inputs.

Our records complement the geologic findings of Denton et al. [1989] by providing information that documents primarily the period since $\sim 6000 \mathrm{yr} \mathrm{BP}$, while the latter covers events $>6000$ yr BP. By contrasting our two ice core records, we test the response of a vast region (the coastal sector of the Transantarctic Mountains) to a dramatic climate perturbation (removal of a grounded ice sheet) and can assess the regional significance of such an event.

\section{SAMPLING AND ANALYTICAL TECHNIQUES}

The Dominion Range core was collected in 19841985 , and two cores (separated by $\sim 50 \mathrm{~m}$ ) were collected from the Newall Glacier in 1988-1989. The higher elevation and latitude of the Dominion Range versus Newall Glacier is expressed in the lower mean annual temperature $\left(-37\right.$ and $-29^{\circ} \mathrm{C}$, respectively, Figure 2) and deeper firn/ice transition $(\sim 0.81 \mathrm{~g}$ $\mathrm{cm}^{-3}$ ) depth (47 and $39 \mathrm{~m}$, respectively, Figure 2). A monopulse system modified after Watts and Isherwood [1978] was used to conduct ground-based radioecho sounding surveys in the drainage basins surrounding each core site. This method yielded estimated ice depths at the core sites of $\sim 220$ and $\sim 225$ $\mathrm{m}$, respectively. A $160 \mathrm{~m}$ core with excellent core quality to $\sim 75 \mathrm{~m}$ was recovered at the Dominion Range site, and two cores to depths of 170 and 150 $m$-with excellent core quality to depths of 50 and 70 $\mathrm{m}$, respectively-were recovered from the Newall site (Figure 2).

All firn/ice sectioning was performed in coldrooms at temperatures that did not exceed $-12^{\circ} \mathrm{C}$ and by personnel using particle masks, plastic gloves and non-particulating clothing. All sample containers were rinsed four times using ultrapure water. Container blanks sampled on a frequent basis showed that the prepared containers were free of contamination. Core processing blanks were also developed by sectioning frozen ultrapure water in the same way that the core samples were prepared. Analyses of these processing blanks showed negligible contamination $(<0.01 \mu \mathrm{eq} / \mathrm{l})$. All chemical analyses were performed with a Dionex Model 4040 ion chromatograph, using techniques described by Mayewski et al. [1990] and Buck et al. [1992], among others. Total 

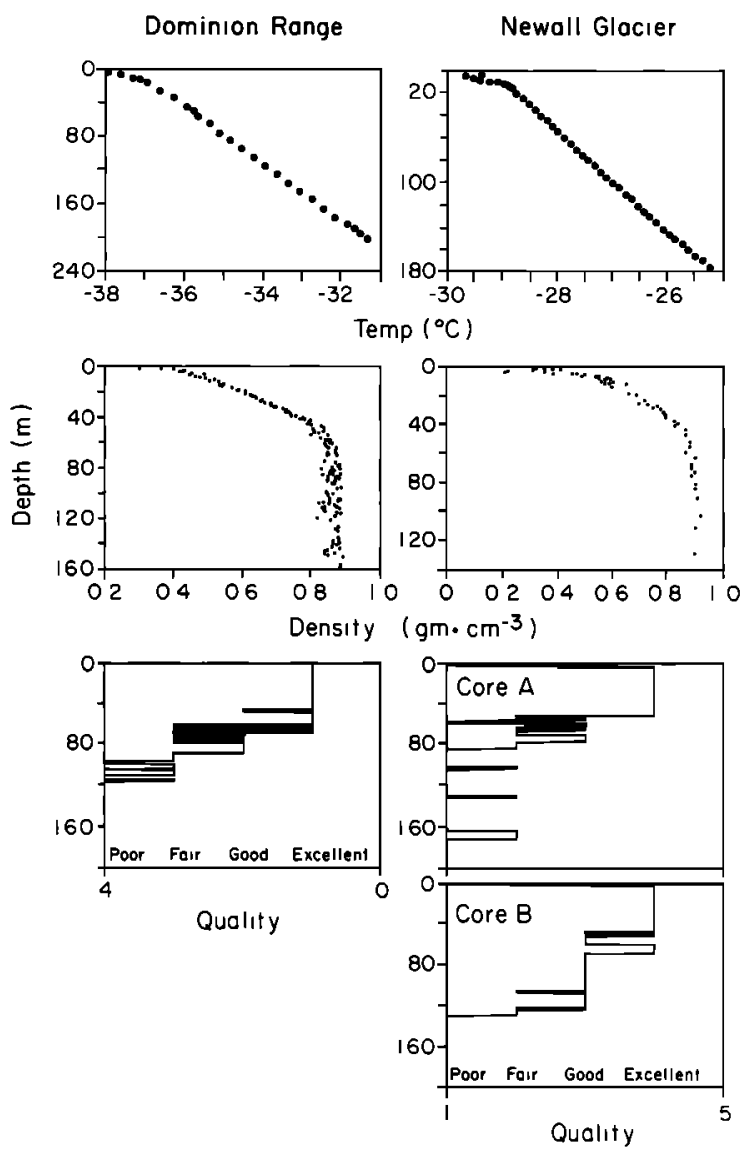

Fig. 2. Downhole temperature, core density and core quality for both sites. Excellent-core contains $<3$ core breaks/m and no fractures. Good-core contains $>3$ to 5 core breaks/m and $<25 \%$ fractures. Fair-core contains $<7$ core breaks $/ \mathrm{m}$ and $<50 \%$ fractures. Poor-core contains $>5$ to 7 core breaks $/ \mathrm{m}$ and/or $>50 \%$ fractures.

beta and ${ }^{210} \mathrm{~Pb}$ activities were determined by methods previously described [Dibb, 1990, 1992]. Beta activity samples were melted and concentrated onto cation exchange filters at McMurdo Station. Oxygen isotope analyses were performed at the University of Washington by gas source mass spectrometry on $\mathrm{CO}_{2}$ equilibrated at $25^{\circ} \mathrm{C}$ with the water samples. Insoluble microparticle concentrations (divided into 64 logarithmically spaced channels from $0.65 \mu \mathrm{m}$ to $13 \mu \mathrm{m}$ ) were determined with an Elzone 280 PC particle counter housed in a Class 100 clean room.

\section{ICE CORE CHRONOLOGIES}

Depth/age relationships for the two core sites were developed by a step-wise process. For the period of the last few decades peaks in total beta activity and ${ }^{210} \mathrm{~Pb}$ decay profiles were employed. For the period covering hundreds to thousands of years major volcanic events were identified and their dating validated by comparison with a simple layer thinning model. Finally, identification of the interglacial/glacial transition was accomplished by major features in the oxygen isotope record.

Suites of samples were collected for beta and ${ }^{210} \mathrm{~Pb}$ activity determinations (Figure 3 ) to aid in the reconstruction of recent chronologies. The Dominion Range beta profile displayed clear peaks at 253 (multiple) and $173 \mathrm{~cm}$, which reflect the first arrival of bomb fallout in Antarctica (summer 1954-1955) and the maximum fallout (summer 1964-1965), respectively. These marker horizons indicate average accumulation rates of 3.5 and $3.4 \mathrm{~g} \mathrm{~cm}^{-2} \mathrm{a}^{-1}$ for the previous 30 and $20 \mathrm{yr}$, respectively. A least squares exponential fit to the ${ }^{210} \mathrm{~Pb}$ profile indicates an average accumulation rate of $3.5 \mathrm{~g} \mathrm{~cm}^{-2} \mathrm{a}^{-1}$ for approximately the preceding century, in very good agreement with the rates determined from total beta marker horizons. Newall Glacier total beta marker horizons were found between 250 and $365 \mathrm{~cm}$, which, based upon fits be-
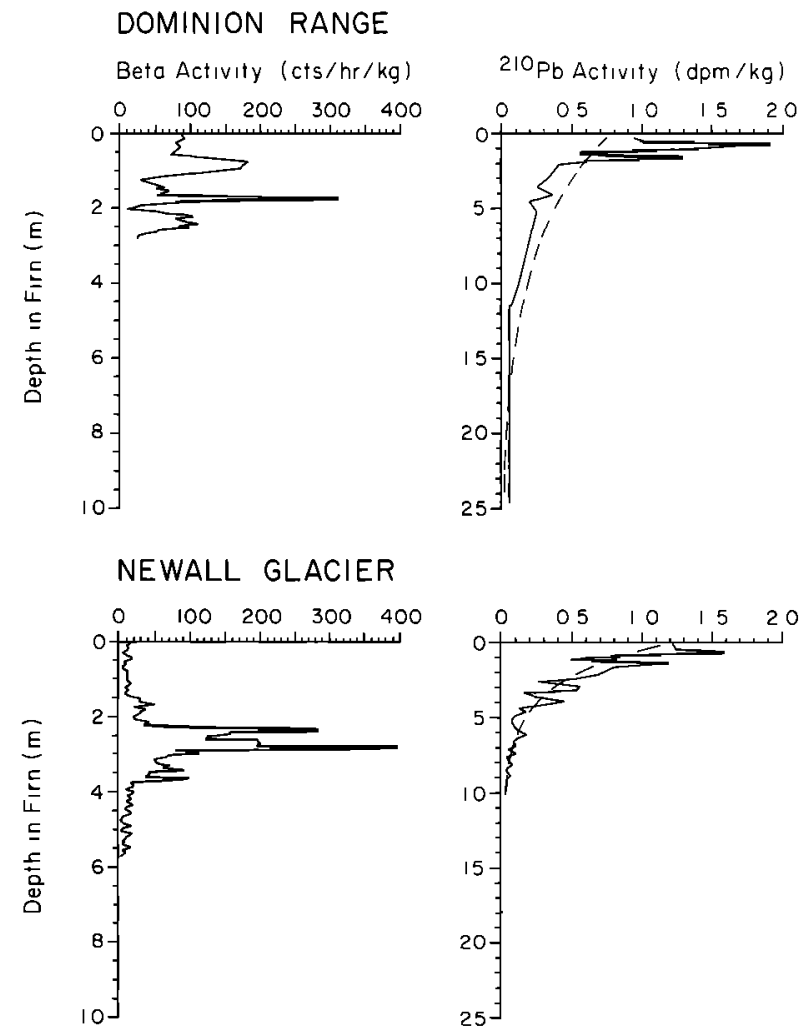

Fig. 3. Beta activity and ${ }^{210} \mathrm{~Pb}$ profiles for both sites. 

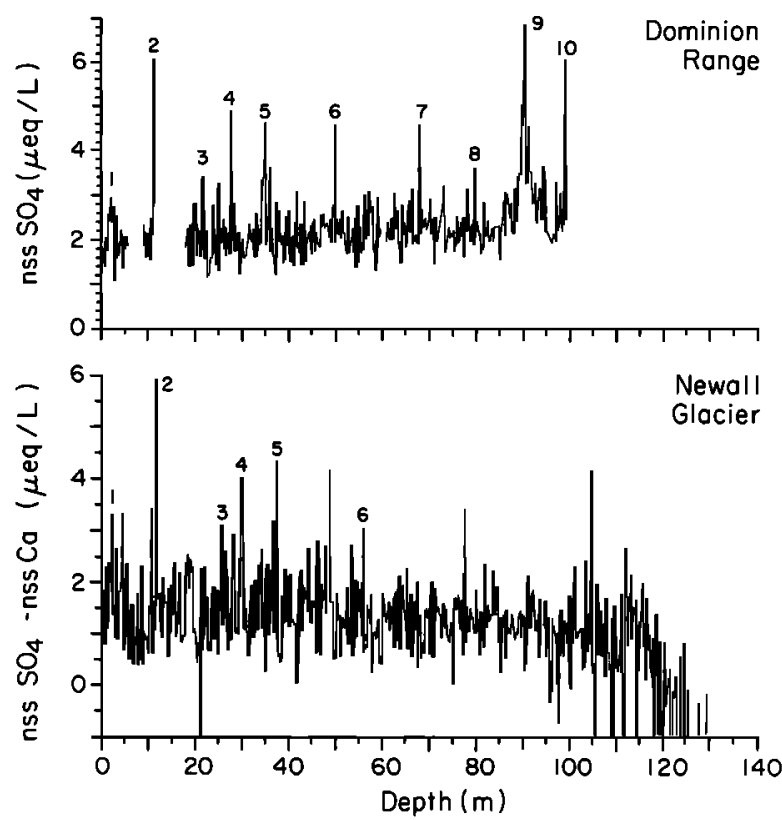

Fig. 4. Nss sulfate (Dominion Range) and nss sulfate minus evaporitic source sulfate (Newall Glacier) depth series used to identify volcanic events. Concentrations in $\mu \mathrm{eq} / \mathrm{l}$. (1) Agung (eruption date 1963 A.D.); (2) Tambora, Subawa (eruption date 1815 A.D.); (3) Huaynaputina, Peru ( 1600 A.D.), equal to Kirchner's [1988] 1635 A.D. event; (4) Mt. St. Helen's (1480 A.D.), equal to Kirchner's [1988] 1450 A.D. event; (5) 1259 event [Langway et al., 1988], equal to Kirchner's [1988] 1250 A.D. event; (6) Rabaul, New Britain ( 540 B.C.); (7) Waimihia, New Zealand ( 1290 B.C.), or Taupo, New Zealand ( 1450 B.C.); (8) Whakataine, New Zealand ( 2840 B.C.); (9) Mt. Mazama, Oregon ( 4650 B.C.); and (10) Towada, Japan ( 6650 B.C.).

tween peaks and fallout dates, yields accumulation rates of 3.7 and $3.8 \mathrm{~g} \mathrm{~cm}^{-2} \mathrm{a}^{-1}$, respectively. The ${ }^{210} \mathrm{~Pb}$ profile yields an average accumulation rate of $3.6 \mathrm{~g} \mathrm{~cm}^{-2} \mathrm{a}^{-1}$.

Kirchner's [1988] 1000-year-long, non-seasalt (nss), sulfate-derived (based on sodium as seasalt indicator [Legrand and Delmas, 1988]) volcanic stratigraphy for South Pole provided guidance for the choice of volcanic events in the Dominion Range since the two sites are relatively close ( $\sim 800 \mathrm{~km}$ apart). At South Pole, seasonal signatures in sodium [Kirchner, 1988] allowed relatively accurate dating to depths in excess of $200 \mathrm{~m}$. Identification of volcanic events in the Dominion Range (Figure 4) is based on the age similarity of these events with those at South Pole. Some of Kirchner's [1988] events have been renamed as well as some small adjustment in dates made based on estimates of the probable interhemispheric volcanic markers for this period (defined by $\mathbf{J}$. Palais and $\mathbf{P}$. Kyle, personal communication, 1991).

Due to the relatively similar surface accumulation rates at Dominion Range and Newall Glacier, the volcanic signatures identified in the Dominion Range core were tentatively assigned to nss sulfate peaks found at nearly equivalent depths at Newall Glacier (Figure 4). For Newall Glacier, peaks in nss sulfate minus estimated sulfate salt concentration (discussed later in this paper) were used in order to remove the potential influence of large local evaporite sources.

Both core sites contain relatively thin ice $(\sim 200$ m), irregular subglacial topography [Mayewski et al., 1990] and potentially high variability in accumulation rate. The proximity of the Newall Glacier site to the Ross Sea, coupled with known Holocene fluctuations in the extent of ice cover over this portion of the Ross Sea, would suggest that variations in accumulation rate are probable, at least at this site. Based on these uncertainties we sought initial guidance in the choice of a layer thinning model for the two sites by utilizing only a simplified, first approximation model. The Haefeli [1961] model employed for this task is not expected to necessarily be suitable

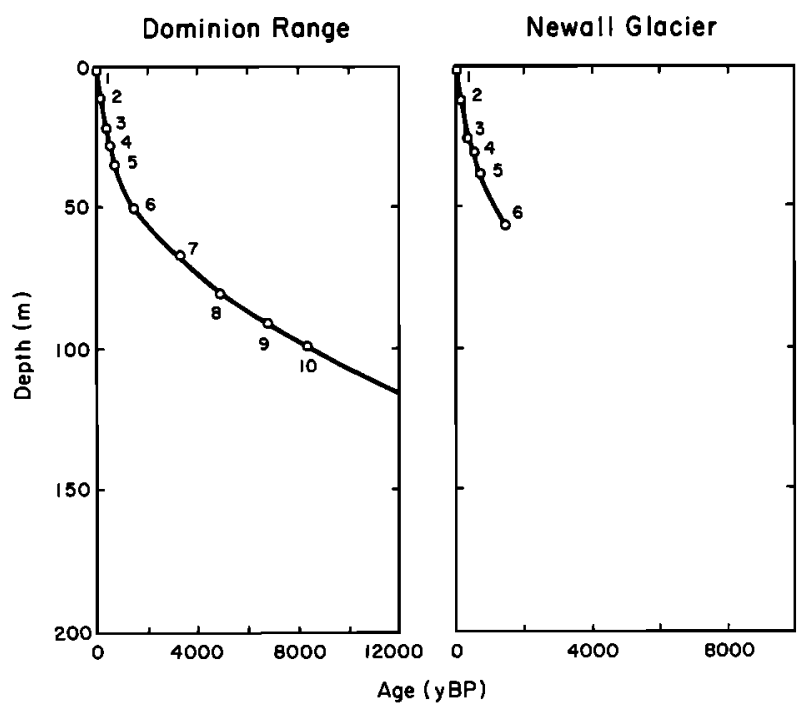

Fig. 5. Depth/age plots developed using Haefeli's [1961] relationship for both sites where the age ( $t$ in yrs) down the core can be computed such that $t=(H / a) \ln (H / H-$ $z$ ), where $H$ is total ice thickness, $a$ is accumulation rate, and $z$ is depth and all are expressed in ice equivalents in $m$. Values for $H$ and $a$ appear in the text. Numbers 1-10 refer to the location of volcanic events. These events are named in the caption for Figure 4. 

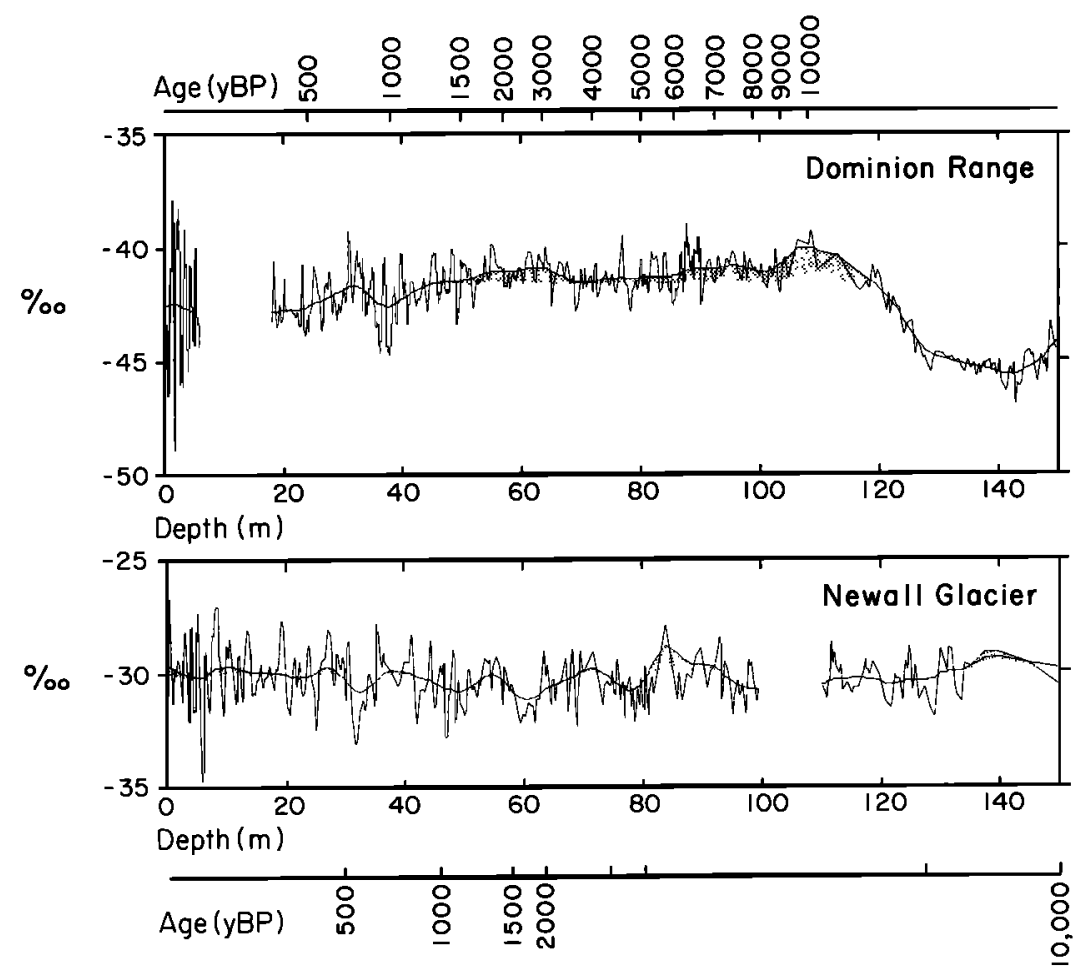

Fig. 6. Oxygen isotope (in $\%$ ) profiles for the Dominion Range and Newall Glacier. Shaded area below smoothed line provides a visual reference for the variability in the two series.

for much more than the upper few hundred years of the record since it assumes uniform vertical strain rate and constant snow accumulation. More sophisticated flow modeling relationships were precluded because of the limited glaciological data available at the sites. Estimated depth/age relationships developed from these simplified layer thinning models allowed us to test the choice of volcanic events at each site (Figure 5). Our volcanic event designations appear to be plausible based on their close correspondence to the layer thinning models.

A rise in oxygen isotopes of $\sim 5.0^{\circ} \%$ from $\sim 130$ to $\sim 110 \mathrm{~m}$ in the Dominion Range core (Figure 6), believed similar to the $5.4^{\circ} \%$ and $\sim 5.0^{\circ} \%$ changes marking the glacial/interglacial transition observed at Dome C [Lorius et al., 1979] and Vostok [Lorius et al., 1985], respectively, is discussed by Mayewski et al. [1990]. Verification of the presence of glacial age ice in the lower section of this core was also based on the analysis of crystal size, fabric, isotopic composition of trapped $\mathrm{O}_{2}$ and $\mathrm{N}_{2}$, and chemistry [Mayewski et al., 1990]. By constraining the deeper end of the Dominion Range record with this oxygen isotope event, we have attempted to estimate the age of the other nss sulfate volcanic events in this record. Since there is no apparent glacial/interglacial transition in the Newall Glacier oxygen isotope record, the accumulation rate at this site must have been higher at some time prior to the period 1259 A.D. to 540 B.C. (the two oldest volcanic events correlated in both the Dominion Range and Newall Glacier cores). We can only estimate that the depth at $\sim 150 \mathrm{~m}$ is less than $\sim 10,000$ yr BP.

\section{OXYGEN ISOTOPES, CHEMISTRY, AND PARTICLES}

The Dominion Range core was initially sampled at selected intervals that were believed, based on in-field electrical conductivity measurements, to contain evidence of strong acid events (potential volcanic signatures) because the identification of these events was essential to the development of the depth/age scale for this record. This primary investigation entailed $3 \mathrm{~cm}$ resolution sampling over sections ranging in length from 1-9 meters. Once a preliminary depth/age scale was developed, the remaining core was analyzed in integrated $20 \mathrm{~cm}$ segments and the 
initial sampling was adjusted to reflect this $20 \mathrm{~cm}$ sampling scheme resulting in a continuously sampled record with a $20 \mathrm{~cm}$ resolution. Unfortunately, sections from 12-18 m (Dominion Range core) and 102$114 \mathrm{~m}$ (Newall Glacier core) were destroyed in transport from McMurdo Station when a freezer unit on board the transport ship malfunctioned.

The Newall Glacier core was sampled continuously in $25 \mathrm{~cm}$ integrated segments to a depth of $128 \mathrm{~m}$. Sampling from $128-169 \mathrm{~m}$ is discontinuous due to decreasing core quality.

\section{Oxygen Isotopes}

Several trends are discernible in the oxygen isotope series (Figure 6). However, the relatively low accumulation rates at both sites have resulted in significant damping of original signals. As noted previously, the Dominion Range record encompasses a near-complete Holocene sequence, extending well past the glacial/interglacial transition, perhaps back to $\sim 30,000 \mathrm{yr}$ BP, based upon a visual comparison with the Vostok record [Lorius et al., 1985; Jouzel et al., 1987]. Oxygen isotope values during the period from the onset of the Holocene $(\sim 120 \mathrm{~m})$ to $\sim 1500 \mathrm{yr}$ BP ( $\sim 45 \mathrm{~m}$ ) suggest relatively mild conditions (less negative) interrupted by a very slight decrease from $\sim 6000-3000$ yr BP. Another low occurs at $\sim 38 \mathrm{~m}$ ( 1000 yr BP), followed by a small increase peaking close to $\sim 32 \mathrm{~m}(\sim 750 \mathrm{yr} \mathrm{BP})$. The variations are all relatively small (less than $\sim 1 \%$ ) and have probably been modified by diffusion as a consequence of the low accumulation rate at this site. The last $\sim 175 \mathrm{yr}$ of record are characterized by relatively low values, although the relationship between this portion of the record and deeper sections cannot be definitively inferred due to the missing section of core between 12 and $18 \mathrm{~m}$. The Newall Glacier oxygen isotope series records only mild fluctuations. In general, the oxygen isotope records from these sites appear to only be valuable in the identification of major climate events (e.g., Holocene versus glacial).

\section{Chemistry}

Major cations (sodium, calcium, potassium and magnesium), major anions (sulfate, chloride and nitrate) and methane-sulfonic acid (MSA) time-series were produced for both cores. To aid in the interpretation of those series, the following summarizes the sources, pertinent reactions and geographic variations of the chemical species found in Antarctic snow and sampled as part of this study.
Although the exact source of nitrate in south polar precipitation is not fully understood, Legrand and Kirchner [1990] suggest that it is a combination of: (1) lightning source nitrate, (2) $\mathrm{NO}_{\mathrm{x}}$ produced from $\mathrm{N}_{2} \mathrm{O}$ oxidation in the lower stratosphere, (3) galactic cosmic rays and/or (4) surface sources such as soils (ice-free valley soils can have extremely high nitrate concentrations [Campbell and Claridge, 1987].

In Antarctica, oxides of nitrogen in the stratosphere are thought to be converted first to $\mathrm{N}_{2} \mathrm{O}_{5}$ and then to nitric acid [McKenzie and Johnson, 1984; Evans et al., 1985]. Since the freezing temperature of a nitric acid-water vapor mixture is higher than that of pure water vapor, polar stratospheric clouds (PSCs) are thought to be composed primarily of frozen nitric acid solutions [Toon et al., 1986]. Nitrate in Antarctic snow is thought to originate primarily from dissolution of gaseous nitric acid in cloud droplets [Legrand and Delmas, 1986]. Rainout of these particles could be a significant source of nitrate to the troposphere and is believed to be linked to the extent and/or persistence of PSCs [Mayewski and Legrand, 1990].

Sulfur is deposited in Antarctic snow primarily as sulfate. This sulfate has five primary sources: (1) natural stratospheric sulfate aerosols; (2) seasalt (ss) aerosol [Delmas and Boutron, 1980; Delmas, 1982; Delmas et al., 1985; Legrand and Delmas, 1988]; (3) oxidation of dimethylsulfide (DMS) produced by phytoplankton and emitted from the oceans; (4) volcanic stratospheric sulfate aerosols; and (5) sulfate associated with evaporitic mineral dusts. The stratospheric aerosol is principally composed of sulfuric acid droplets formed from decomposition of sulfur gases such as carbonyl sulfate and sulfur dioxide [Turco et al., 1982]. Seasalt aerosol contains particulate sulfate as well as other major ss components. The deposition of this coarse-sized aerosol in Antarctic snow rapidly decreases with distance inland or elevation [Delmas and Boutron, 1980] and comprises only about $10 \%$ of total sulfate deposition at inland sites in Antarctica, such as Dome C.

According to Charlson et al. [1987], DMS is the major reduced sulfur gas in the marine atmosphere. DMS is excreted by phytoplankton; however, the level of excretion is highly species-dependent. In the troposphere, DMS reacts with hydroxyl radical to form sulfur dioxide and methane-sulfonic acid (MSA). Sulfur dioxide is oxidized further, forming sulfuric acid aerosol. This aerosol is ubiquitous in the marine atmosphere and serves as the major source of cloud condensation nuclei in these areas [Charlson et al., 1987]. According to Shaw [1982], this fine aerosol 


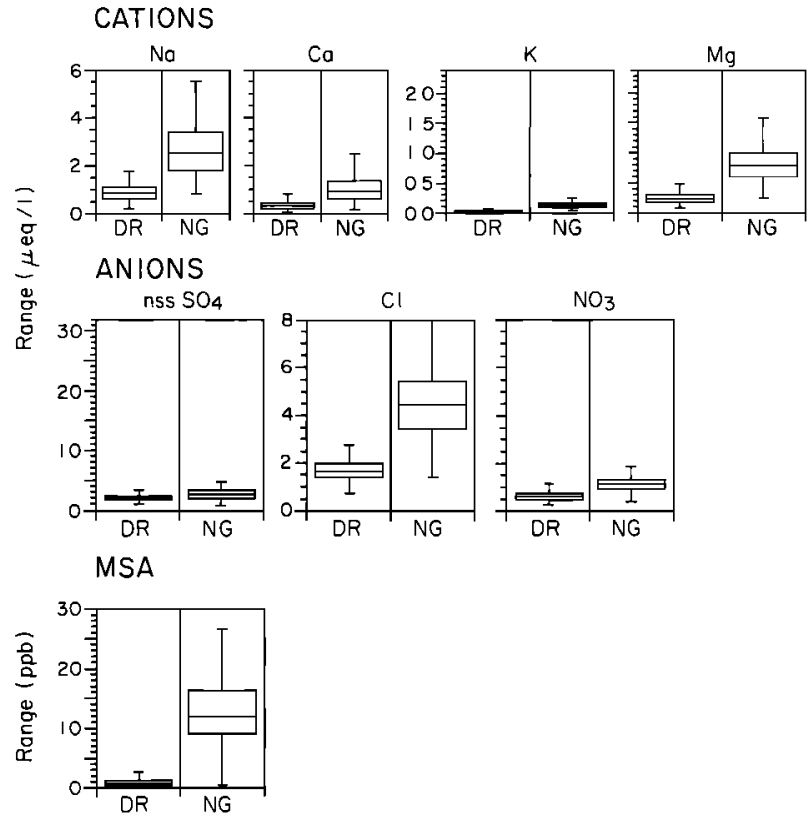

Fig. 7. Box plots displaying the integrated 1000 yr chemistry at both sites. Box encompasses the mean value $\pm 25 \%$. Capped line contains $5-95 \%$ of the data. DR, Dominion Range; NG, Newall Glacier.

is distributed throughout the Antarctic troposphere and accounts for the majority of the non-seasalt (nss) sulfate deposited in snow [Delmas, 1982]. High concentrations of MSA in the atmosphere are associated with areas of high DMS flux from the ocean to the atmosphere.

Three sources are known for chloride found in Antarctic snow: (1) marine seasalt (assuming that sodium is the primary seasalt indicator [Legrand and Delmas, 1988]); (2) $\mathrm{HCl}$ emitted during volcanic eruptions; and (3) $\mathrm{HCl}$ which is released upon reaction of sulfuric acid with ss particles [Herron, 1982].

Magnesium, calcium and potassium have two potential sources: seasalt (based on the use of sodium as the seasalt indicator [Legrand and Delmas, 1988]) and crustally derived aerosol. Near the coast the ss-derived calcium and potassium predominate [Boutron, 1980; Boutron and Martin, 1980; Aristarain et al., 1982; Herron, 1982; Mumford and Peel, 1982]. Increases in crustal sources of these species, as well as of silicate and iron, have been interpreted as indicators of increased atmospheric turbidity and/or of increases in the exposure of ice-free areas [Mayewski and Lyons, 1982a; Mumford and Peel, 1982].

Since both the Newall and the Dominion Range cores have similar accumulation rates over the last $\sim 1000 \mathrm{yr}$, and because prior to this period there is a dramatic change in the accumulation rate and chemical composition of the Newall record, general comparison of the bulk chemistry of these two cores is restricted to this period. Figure 7 is a box plot representing the major differences in chemistry between the two sites for this period. The closer proximity of the Newall site to the ocean and to extensive ice-free areas containing dusts and evaporitic minerals is reflected by higher concentrations of marine source species - sodium, chloride, magnesium, potassium and MSA-and crustal source species (including evaporites)-sodium, chloride, magnesium, potassium, calcium, sulfate and nitrate. $\mathrm{The}^{\mathrm{SO}} \mathrm{S}_{4} \mathrm{Cl}$ ratio of Newall snow is twice that of seawater, while the $\mathrm{Ca}: \mathrm{Na}$ ratio is $\sim 9 \times$ greater than seawater. This increase of $\mathrm{Ca}^{2+}$ and $\mathrm{SO}_{4}^{2+}$ in Newall precipitation relative to seasalt is apparent throughout the entire timeframe represented by this core.

Several broad patterns of change can be identified in the Dominion Range chemical series (Figure 8), including: an increase in all species (except nitrate) peaking at $\sim 90 \mathrm{~m}$; a fluctuating decline in calcium from $\sim 90-45 \mathrm{~m}$; an increase in nitrate between $\sim 50-0$ $\mathrm{m}$; an increase in MSA from $\sim 40-0 \mathrm{~m}$; and a rise in calcium, sodium and potassium within the upper $\sim 10$ $m$ of the record.

Since the sources of the species which display increased levels peaking at $\sim 90 \mathrm{~m}(\sim 7000 \mathrm{yr} \mathrm{BP})$ are both marine (sodium, chloride, magnesium, potassium, nss sulfate and MSA) and continental (calcium, nss sulfate, sodium, magnesium and potassium), it appears that either circulation strength was relatively more intense and/or marine and terrestrial dust sources were greater (more ice-free area). Concentrations during this period ( $7000 \mathrm{yr} B \mathrm{BP}$ ) are closer to those currently characterizing Newall Glacier. Levels of all species except those characterizing the marine environment (sodium, chloride, nss sulfate and MSA) stay relatively high until $\sim 75 \mathrm{~m}(\sim 4000 \mathrm{yr}$ BP), suggesting that marine air incursions to this site had declined prior to this time. Decreasing levels of calcium from $90-45 \mathrm{~m}$ ( 7000- 1250 yr BP) suggest that during this period either transport strength weakened and/or the extent of local ice-free areas decreased (increased snow cover).

The marked increase in nitrate from $\sim 50-0 \mathrm{~m}$ coincides with the period $\sim 1500-0$ yr BP. Recent increases in nitrate at South Pole and Dominion Range have been proposed by Mayewski and Legrand [1990] as indicative of increased persistence and/or extent of polar stratospheric clouds (PSCs). Since PSCs serve as a major reservoir for the multi-source nitrate found in the atmosphere over Antarctica, the periods of in- 


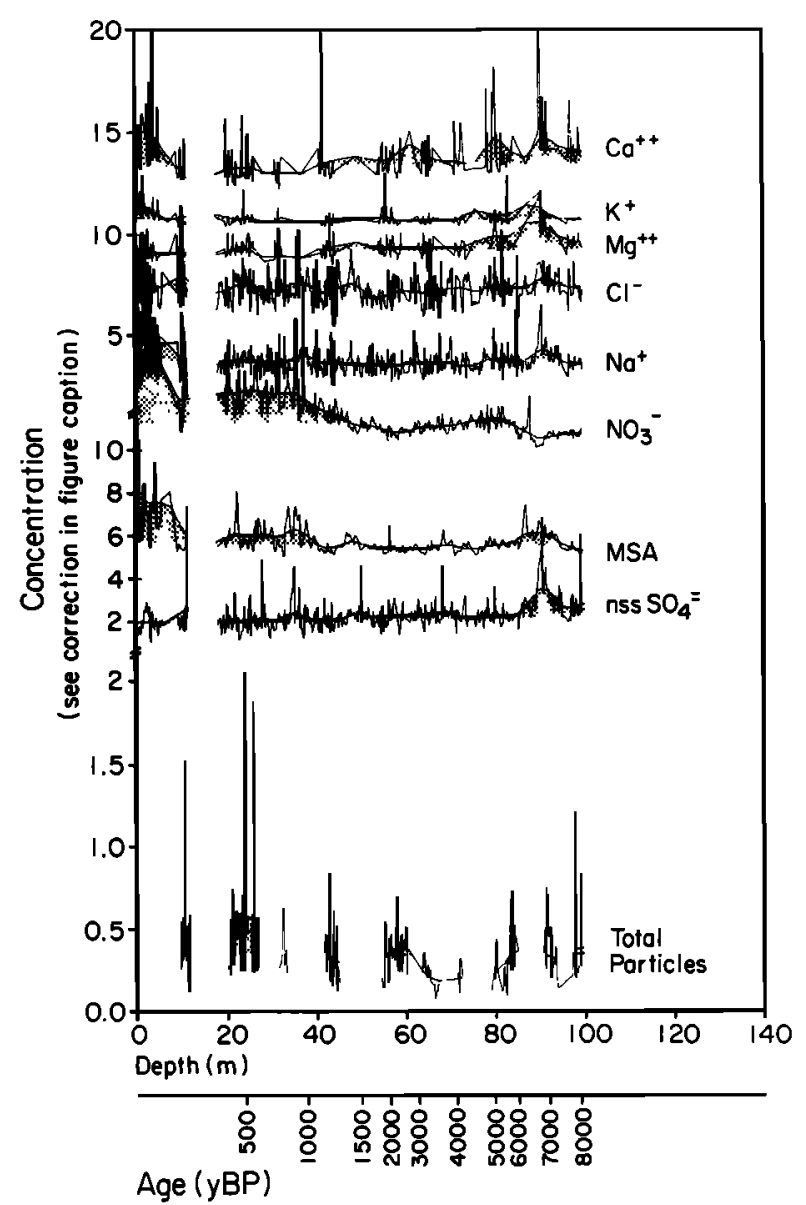

Fig. 8. Dominion Range chemical and particle series. All concentrations in $\mu$ eq/l except MSA (in ppb) and particles (number). Conversion for true concentration is (calcium/5)-12, (potassium/20)-10.5, (magnesium/5)8, (chloride/2)-4, (sodium/2)-2, (nitrate/5)-1, MSA/100, nss sulfate/1, and total particles (105). Smoothed line through original data is a triangular filter moved over 10 m sections. Shaded area below smoothed line provides a visual reference for the variability in the smoothed series. Missing sections in the total particles plot represent areas in which insufficient sample volume and/or core quality prevented analysis.

creased nitrate deposition at the Dominion Range site may provide a paleorecord of PSC extent and/or persistence. (Increases in either lead to increased likelihood of nitrate deposition on the ice sheet.)

Levels of MSA increase between $\sim 40-0 \mathrm{~m}(\sim 100-$ 0 yr BP). Peaks in MSA at South Pole have been correlated with the incursion of upper tropospheric or lower stratospheric air masses [Legrand and FenietSaigne, 1991], while increases in MSA closer to the coast, at Newall Glacier, have been suggested to be directly related to increases in sea ice cover [Welch et al., 1993]. The increases in MSA observed in the Dominion Range appear to represent an increase in the transport of marine biogenic source air masses to the Dominion Range either by intensified transport from ocean sources and/or increased source strength.

The rise in sodium, potassium and calcium from $\sim 10-0 \mathrm{~m}$ (the last $\sim 150 \mathrm{yr}$ ) is not paralleled by an increase in chloride or other marine species. Hence this increase would appear to reflect an increase in transport of crustal material to the site and/or an increase in local sources (an increase in the extent of local ice-free terrain).

Among the notable features in the Newall Glacier chemistry series (Figure 9) are markedly higher levels below $120 \mathrm{~m}$ for all species except nitrate (which

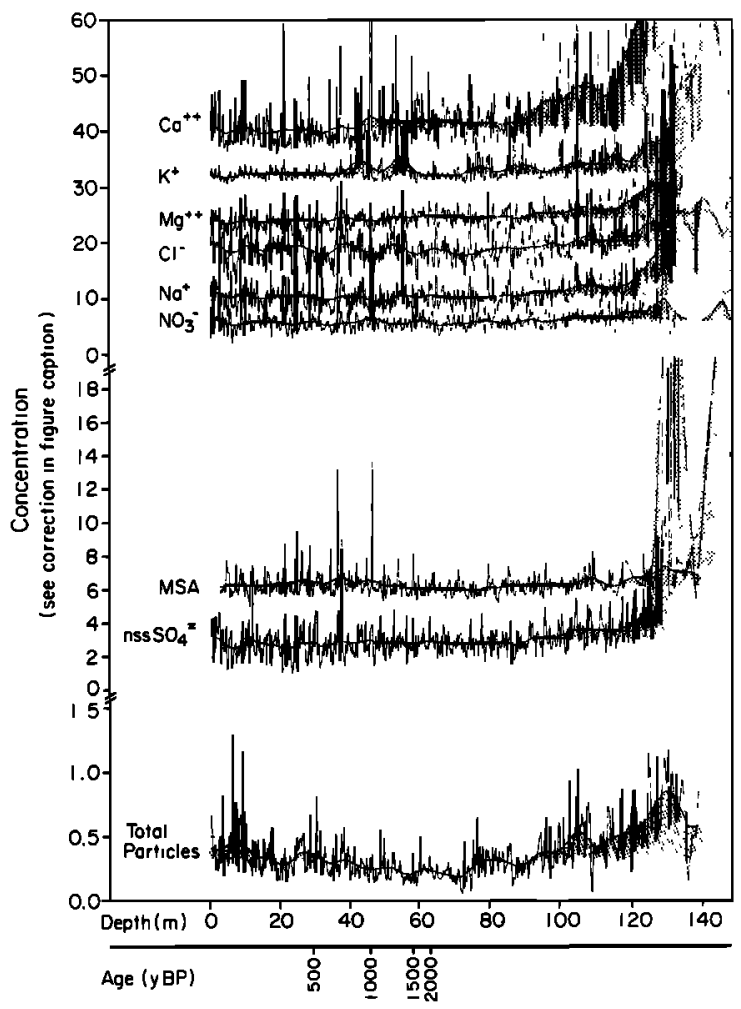

Fig. 9. Newall Glacier chemical and particle series. All concentrations in $\mu$ eq/ $/$, except MSA (in ppb) and particles (number). Conversion for true concentration is (calcium/5)-35, (potassium/20)-30, (magnesium/5)20, (chloride/2)-10, (sodium/2)-5, nitrate/5, MSA/10, nss sulfate/1, and total particles (105). Smoothed line through original data is a triangular filter moved over 10 m sections. Shaded area above smoothed line provides a visual reference for the variability in the smoothed series. 
peaks before and after $\sim 130 \mathrm{~m}$ ), followed by a fluctuating decline. Concentrations drop at progressively shallower depths in the order: nitrate, MSA, chloride, nss sulfate, magnesium, sodium, potassium and calcium. Levels of MSA increase slightly from $\sim 50$ $20 \mathrm{~m}$, and all species except MSA, potassium and magnesium increase very moderately in the $\sim 10-0 \mathrm{~m}$ range.

Major ion concentrations (excluding nitrate) 3 to 10 times the average characterize the Newall core below $120 \mathrm{~m}$ (Figure 9). Although sampling is discontinuous over this interval, dramatic variations in concentration between some pairs of adjacent samples are still evident, implying episodic inputs. A variety of salts characterize this interval. However, the data available do not allow a unique identification of these salts.

A major distinction between the three compositional groups defined in this study is the $\mathrm{Cl}: \mathrm{Na}$ ratio and the $\mathrm{Ca}:(\mathrm{Na}+\mathrm{K}+\mathrm{Mg})$ ratio. Carbonate was not analyzed but is assumed to be an important component. We have calculated the carbonate concentration by balancing the cations and anions in each sample.

Spot samples were collected below $145 \mathrm{~m}$ in portions of the core that were of sufficient quality to sample. Although not included in Figure 9, three of the four samples analyzed (from 152-169 m) are characterized by a $\mathrm{Cl}: \mathrm{Na}$ ratio of 1 . One of these three (from $152 \mathrm{~m}$ ) is additionally characterized by a $\mathrm{Ca}:(\mathrm{Na}+\mathrm{K}+\mathrm{Mg})$ ratio of 3 . The excess $\mathrm{Ca}$ in this sample is interpreted as representing inputs of $\mathrm{CaSO}_{4} \cdot 2 \mathrm{H}_{2} \mathrm{O}$ and $\mathrm{CaCO}_{3}$. From $150-132 \mathrm{~m}$, the samples are characterized by $\mathrm{Cl}: \mathrm{Na}$ ratios of 2.0-2.5 and a $\mathrm{Ca}:(\mathrm{Na}+\mathrm{K}+\mathrm{Mg})$ ratio less than 1 . Calcium again exceeds sulfate. Our calculated carbonate values exceed $\sim 4$, with a maxima $\sim 50 \mu \mathrm{eq} / \mathrm{l}$. This sequence is interpreted to reflect high inputs of chloride-rich salts and $\mathrm{CaCO}_{3}$. The very high $\mathrm{Cl}: \mathrm{Na}$ ratio precludes a major influx of mirabilite and also indicates that alkaline metal and probably chloride salts such as $\mathrm{KCl}$, $\mathrm{MgCl}_{2}$ and even $\mathrm{CaCl}_{2}$ are important contributors. Saline groundwaters, as well as the deep waters of Lake Vanda in Wright Valley, have well documented chemistries [Matsubaya et al., 1979; Cartwright and Harris, 1981]. These waters are unusual in having very high $\mathrm{Ca}: \mathrm{Na}$ and $\mathrm{Ca}: \mathrm{Mg}$ ratios. The $\mathrm{K}: \mathrm{Na}$ ratio of the deep lake waters is also greater than that of seawater. If these waters were to evaporate completely, they would produce Cl-rich salts in the order $\mathrm{Ca}>\mathrm{Mg} \approx \mathrm{Na}>\mathrm{K}$. This is similar to the relative distribution of these cations in this depth interval.
From 132-118 m, the Cl:Na ratio is greater than 1, as is the $\mathrm{Ca}:(\mathrm{Na}+\mathrm{K}+\mathrm{Mg})$ ratio. Although the calculated carbonate values are lower here than at the previously mentioned depth, they are still high, with values ranging between $\sim 2$ and $8 \mu \mathrm{eq} / \mathrm{l}$. These samples reflect higher amounts of $\mathrm{CaCO}_{3}$, and perhaps $\mathrm{CaCl}_{2}$, relative to other salts than do the deeper sections. The $\mathrm{Na}: \mathrm{SO}_{4}$ ratios vary around 2 , suggesting the possible importance of mirabilite. By $118 \mathrm{~m}$, the concentrations of the major ions have fallen to levels typical of the remaining core, with characteristic $\mathrm{Cl}: \mathrm{Na}$ and $\mathrm{Ca}:(\mathrm{Na}+\mathrm{K}+\mathrm{Mg})$ ratios greater than 1 and less than 1 , respectively.

The input of locally derived evaporitic dusts described above reflects environmental conditions that have not recurred at the Newall site. They also imply a salt source much larger than is available today. The evaporitic dust influx was more than 250 times greater (based only on carbonate input) during this highest evaporitic input period. The probable source of these evaporitic materials is adjacent Taylor and Wright Valleys. Today these valleys contain a number of ice-covered lakes, including both stratified saline (e.g., Lake Vanda and Lake Bonney) and fresh water (e.g., Lake Fryxell and Lake Hoare) lakes [Matsubaya et al., 1979; Green et al., 1988]. The volumes of these lakes fluctuated greatly over the time period 4750 6000 yr BP, with both lower levels and higher levels having been demonstrated [Wilson, 1964; Lawrence and Hendy, 1985]. High levels occur during more "humid" periods, and low levels during more "arid" periods [Lawrence and Hendy, 1985]. Moisture availability could have been controlled by alternations between open and closed ocean conditions in the Ross Sea. The transition from humid to arid conditions allowed for massive amounts of salts to be produced on the valley floors as well as in residual lake basins [Lawrence and Hendy, 1985; Lyons et al., 1985].

Increased levels of MSA noted above and between $\sim 50-20 \mathrm{~m}(\sim 1250-300$ yr BP) suggest that marine productivity source areas were either closer to the core site or that increased transport to the site was achieved. Welch et al. [1993] have demonstrated a correlation between increased Ross Sea sea ice extent and increased Newall Glacier core MSA levels over the last few decades. Gibson et al. [1990] provide the process linking MSA and sea ice extent, citing direct measurements relating sea ice extent with increased DMS production by phytoplankton. Using this ana$\log$, the periods documented by increased MSA levels are assumed to be periods of sea ice growth and attendant increased marine productivity. 
Relatively minor increases in marine source species such as sodium, chloride and nss sulfate, plus terrestrial source species such as calcium and sodium plus nitrate (potentially an evaporitic source for this site) within the upper $10 \mathrm{~m}$ of the core $(<150 \mathrm{yr} \mathrm{BP})$ indicate an increase in the exposure of ice-free terrain and open ocean or evaporite source inputs.

\section{Particles}

Figures 8 and 9 show downcore concentrations for total particles $(<13 \mu \mathrm{m})$ for both cores. Plots for the other size ranges investigated-fine $(<1 \mu \mathrm{m})$, medium (1-3.2 $\mu \mathrm{m})$ and coarse (3.2-13 $\mu \mathrm{m})$-are not presented because at both sites they parallel closely those for total particles. Increases in particle concentrations have been routinely related to increases in circulation strength and/or source area.

Most notable in the Dominion Range particle record is the decrease in concentration between $\sim 80$ $60 \mathrm{~m}(\sim 5000-2500 \mathrm{yr} \mathrm{BP})$ and the increase at $\sim 30$ $\mathrm{m}(\sim 750$ yr BP) that cannot be definitively followed above $\sim 20 \mathrm{~m}$ due to missing sections of core. The period of decrease parallels a decrease in calcium which has been interpreted as the product of decreased terrestrial source input (a result of decreased source area and/or transport strength). The increase in particles since $\sim 750$ yr BP is not completely paralleled by an increase in calcium. It is possible that the majority of the particles measured are not calcium but rather silicate or iron. These species are commonly exposed in the Transantarctic Mountains. Increased ice-free exposure and/or circulation strength would lead to their incorporation into the core.

The total number of particles in the Newall core closely parallel trends in the primary evaporite source chemical species in sections $>90 \mathrm{~m}$ in depth. Increased particle levels appear again at $<30 \mathrm{~m}$ depth ( $<500$ yr BP). Newall Glacier chemical series display some increases below $30 \mathrm{~m}$ depth but not sufficient to closely parallel the particle record. This particle increase may also reflect increased input of terrestrial source species such as silicate and iron, not measured in this study.

\section{CONCLUSIONS}

An estimate of the late Holocene paleoenvironment of the Transantarctic Mountains is developed on the basis of two multivariate ice core records. The more southerly Dominion Range site yields an $\sim 30,000$-year-long record, and the Newall Glacier, to the north, reveals a $<10,000$-year-long record. Accumulation rates at both sites are quite low $(\sim 3.0 \mathrm{~g}$ $\mathrm{cm}^{-2} \mathrm{a}^{-1}$ ), preventing the dating accuracy and attendant statistical analyses possible at higher accumulation sites $\left(>20 \mathrm{~g} \mathrm{~cm}^{-2} \mathrm{a}^{-1}\right)$. As a3 consequence, details of shorter period oscillations in climate on the order of decades to $<500 \mathrm{yr}$ cannot be adequately addressed in this study. However, the records from these sites are still extremely valuable, since little is known about even the long-period ( $1000 \mathrm{yr})$ elements of the late Holocene history of the Transantarctic Mountains. Differences in the paleoclimatic records retrieved from the Dominion Range and Newall Glacier ice core sites suggest that the Transantarctic Mountain region has experienced a regionally diverse and dynamic climate history during the Holocene that warrants further investigation utilizing higher accumulation rate records (higher resolution).

Comparison of the two multivariate ice core records from the Transantarctic Mountains, combined with glacial geologic, glaciological and sediment information, reveals several paleoenvironmental divisions which are summarized chronologically.

\section{$\sim 10,000-\sim 6000$ yrBP}

From $\sim 10,000$ yr BP to $\sim 6000$ yr BP, relative temperatures based on oxygen isotopic measurements suggest that the climate in the southern Transantarctic Mountains (Dominion Range) was relatively mild. By no later than $\sim 7000$ yr BP, terrestrial, seasalt and marine biogenic influences were at their Holocene peak in this region, suggesting the presence of increased ice-free areas and intensified transport of marine source tropospheric air masses to the region. By $\sim 6000$ yr BP, marine source tropospheric air masses no longer penetrated this far south with the same intensity, but local ice-free terrain was relatively extensive.

\section{$\sim 6000-\sim 1500 \mathrm{yr} B P$}

To the south in the Dominion Range, the oxygen isotope record provides evidence of slightly cooler conditions from $\sim 6000-3500 \mathrm{yr} \mathrm{BP}$, and the extent of ice-free exposure declined through this period. Prior to $\sim 4000 \mathrm{yr} \mathrm{BP}$, the influence of marine air masses in this region had declined markedly. Conditions in the Dominion Range became gradually milder during the period $\sim 3500-1500$ yr BP. Terrestrial input to the core increased from $\sim 3000-2000$ yr BP as ice-free exposure increased in extent. 
To the north along the coast of southern Victoria Land, a grounded Ross Ice Sheet had retreated completely from McMurdo Sound [Denton et al., 1989] by $\sim 6600-6020$ yr BP. Accumulation rates at Newall Glacier were markedly higher than today sometime between $\sim 2000$ and $\sim 10,000 \mathrm{yr} B P$, we assume in response to the deglaciation of McMurdo Sound and increased availability of moisture. Prior to this period of increased accumulation, Newall Glacier may not have been as large an ice mass as it is currently (available moisture would have been severely restricted). Evaporite salts dominate the Newall record below 120 $m$ depth (a probable result of the lowering of lake levels formerly dammed by the Ross Ice Sheet). Once initiated, fluctuations in lake levels continued to characterize the region as a result of fluctuations in available moisture, due perhaps to alternations in sea ice extent, which are documented in the ice core by increased marine productivity [Welch et al., 1993].

\section{$\sim 1500$ yr BP - Present}

Since $\sim 1500$ yr BP, the persistence and/or extent of PSCs over the Dominion Range increased, responding perhaps to cooler temperatures and/or increased moisture content aloft. Relative temperatures inferred from the oxygen isotope record suggest cooling at $1000 \mathrm{yr}$ BP preceded and followed by warming, although this record is probably not indicative of temperatures at altitudes containing PSCs. Transport to the region of air masses with a marine biogenic imprint increased as of $\sim 1000$ yr BP. As early as $\sim 750$ yr BP, atmospheric circulation strengthened, and/or source regions for dusts affecting the region increased. By $\sim 150$ yr BP, terrestrial dust levels increased in response to increased exposure of ice-free terrain and/or continued intensification of atmospheric circulation in the region.

From $\sim 2000$ yr BP to present, relative temperatures inferred from oxygen isotope measurements at Newall Glacier rose slightly, accumulation rates remained low, and sea ice extent inferred from marine productivity fluctuated (highest $\sim 1250-300 \mathrm{yr}$ $\mathrm{BP})$. As of $\sim 500 \mathrm{yr} \mathrm{BP}$, particle levels increased, suggesting strengthening of atmospheric circulation and/or larger source areas for dust entering the core site. Within the last $\sim 150 \mathrm{yr}$, seasalt, terrestrial and perhaps evaporitic salt inputs to the region increased slightly, suggesting some increased transport of marine tropospheric air masses to the region, increased areal extent of ice-free terrain and lower lake levels. Complementary evidence suggesting similar conditions comes from Meserve Glacier (Wright Valley), where increased exposure of ice-free terrain since $\sim 325$ yr BP has been documented [Mayewski and Lyons, 1982b], and Lake Hoare (Taylor Valley), where lake ice thinning has been documented since 1972 A.D. [Wharton et al., 1992].

Acknowledgments. We would like to thank several colleagues for their involvement in various aspects of our field and laboratory investigations: Chris Buck, Henry Rufli, Barry Lopez and Michael Morrison. The Polar Ice Coring Office (University of Nebraska, Lincoln) accompanied the field team and provided the equipment and personnel (Bruce Koci, Scott Watson and Ted Clarke) to recover the ice cores used in this study. Support in the field was provided by the efforts of VXE-6 and Antarctic Support Services. This research was supported by NSF DPP grants 8411018 and 8613786 .

\section{REFERENCES}

Aristarain, A. J., R. J. Delmas, and M. Briat, Snow chemistry on James Ross Island (Antarctic Peninsula), J. Geophys. Res., 87, 11,004-11,012, 1982.

Boutron, C., Respective influence of global pollution and volcanic eruptions on the past variations of the trace metals content of Antarctic snows since $1880 \mathrm{~s}, J$. Geophys. Res., 85, 7426-7432, 1980.

Boutron, C., and S. Martin, Sources of twelve trace metals in Antarctic snows determined by principal component analysis, J. Geophys. Res., 85, 5631-5638, 1980.

Buck, C. F., P. A. Mayewski, M. J. Spencer, S. Whitlow, M. S. Twickler, and D. Barrtett, The determination of major ions in snow and ice cores by ion chromatography, J. Chromatogr., 594, 225-228, 1992.

Campbell, I. B., and G. C. C. Claridge, Antarctica: Soils, Weathering Processes and Environment, Dev. in Soil Sci., vol. 16, 368 pp., Elsevier, New York, 1987.

Cartwright, K., and H. J. H. Harris, Hydrogeology of the dry valley region, Antarctica, in Dry Valley Drilling Project, Antarct. Res. Ser., vol. 33, edited by L.D. McGinnis, pp. 193-214, AGU, Washington, D.C., 1981.

Charlson, R. J., J. E. Lovelock, M. O. Andreae, and S. G. Warren, Oceanic phytoplankton, atmospheric sulfur, cloud albedo and climate, Nature, 326, 655661, 1987.

Delmas, R. J., Antarctic sulfate budget, Nature, 299, 677-678, 1982.

Delmas, R.J., and C. Boutron, Are the past variations of the stratospheric sulfate burden recorded in central 
Antarctic snow and ice layers?, J. Geophys. Res., 85, 5646-5649, 1980.

Delmas, R. J., M. Legrand, A. J. Aristarain, and F. Zanolini, Volcanic deposits in Antarctic snow and ice, J. Geophys. Res., 90, 901-920, 1985.

Denton, G. H., J. G. Bockheim, S. C. Wilson, and M. Stuiver, Late Wisconsin and early Holocene glacial history, Inner Ross Embayment, Antarctica, Quat. Res., 31, 151-182, 1989.

Dibb, J. E., Recent deposition of ${ }^{210} \mathrm{~Pb}$ on the Greenland Ice Sheet, Ann. Glaciol., 14, 51-54, 1990.

Dibb, J. E., The accumulation of ${ }^{210} \mathrm{~Pb}$ at Summit, Greenland, since 1855, Tellus, 44B, 72-79, 1992.

Evans, W. F. J., C. T. McElroy, and I. E. Galbally, The conversion of $\mathrm{N}_{2} \mathrm{O}_{5}$ to $\mathrm{HNO}_{3}$ at high latitudes in winter, Geophys. Res. Lett., 12, 825-828, 1985.

Gibson, J. A. E., R. C. Garrick, J. R. Burton, and A. R. McTaggart, Dimethylsulfide and the algae Phaecystis pouchetii in Antarctic coastal waters, Mar. Biol., 104, 339-346, 1990.

Green, W. J., M. P. Angle, and K. E. Chane, The geochemistry of Antarctic streams and their role in the evolution of four lakes of the McMurdo dry valleys, Geochim. Cosmochim. Acta, 52, 1265-1274, 1988.

Grove, J. M., The Little Ice Age, 387 pp., Routledge, New York, 1988.

Haefeli, R., Contribution to the movement and the form of ice sheets in the Arctic and Antarctic, J. Glaciol., 3, 1122-1151, 1961.

Herron, M. M., Impurity source of $\mathrm{F}^{-}, \mathrm{Cl}^{-}, \mathrm{NO}_{3}{ }^{-}$, and $\mathrm{SO}_{2}=$ in Greenland and Antarctic precipitation, $J$. Geophys. Res., 87, 3052-3060, 1982.

Jouzel, J., C. Lorius, J. R. Petit, C. Genthon, N. I. Barkov, V. M. Kotlyakov, and V. N. Petrov, Vostok ice core: A continuous isotope temperature record over the last climatic cycle $(160,000 \mathrm{yr})$, Nature, 329 , 403-408, 1987.

Kirchner, S., Chimie de la neige a la station South Pole, Ph.D. dissertation, Centre Natl. de la Rech. Sci., Paris, 1988.

Lawrence, M. J. F., and C. H. Hendy, Water column and sediment characteristics of Lake Fryxell, Taylor Valley, Antarctica, N. Z. J. Geol. Geophys., 28, 543552, 1985.

Legrand, M., and R. J. Delmas, Relative contributions of tropospheric and stratospheric sources to nitrate in Antarctic snow, Tellus, $38,236-249,1986$.

Legrand, M., and R. Delmas, Formation of $\mathrm{HCl}$ in the Antarctic atmosphere, J. Geophys. Res., 93, 7153$7168,1988$.

Legrand, M., and C. Feniet-Saigne, Methanesulfonic acid in South Polar snow layers: A record of strong $\mathrm{El}$ Nino?, Geophys. Res. Lett., 18, 187-190, 1991.

Legrand, M., and S. Kirchner, Origins and variations of nitrate in South Polar precipitation, J. Geophys.
Res., 95, 3493-3507, 1990.

Lorius, C., L. Merlivat, J. Jouzel, and M. Pourchet, A 30,000-yr isotope climatic record from Antarctic ice, Nature, 280, 644-648, 1979.

Lorius, C., J. Jouzel, C. Ritz, L. Merlivat, N. I. Barkov, Y. S. Korotkevich, and V. M. Kotlyakov, A 150,000year climatic record from Antarctic ice, Nature, 316, 591-596, 1985.

Lyons, W. B., P. A. Mayewski, L. G. Thompson, and B. Allen, The glaciochemistry from 1982 snowpits from Quelccaya Ice Cap, Peru, Ann. Glaciol., 7, 84-88, 1985.

Matsubaya, O., H. Sakai, T. Torn, H. Burton, and K. Kerry, Antarctic saline lakes-Stable isotopic ratios, chemical compositions and evolution, Geochim. Cosmochim. Acta, 54, 205-215, 1979.

Mayewski, P. A., and M. R. Legrand, Recent increase in nitrate concentration of Antarctic snow, Nature, 346, 258-260, 1990.

Mayewski, P. A., and W. B. Lyons, Source and climatic implication of the reactive iron and reactive silicate concentrations found in a core from Meserve Glacier, Antarctica, Geophys. Res. Lett., 9, 190-192, 1982a.

Mayewski, P. A., and W. B. Lyons, Meserve ice core reactive iron and reactive silicate concentrations, Geophys. Res. Lett., 9, 190-192, 1982b.

Mayewski, P. A., M. S. Twickler, W. B. Lyons, M. J. Spencer, D. A. Meese, A. J. Gow, P. Grootes, T. Sowers, M. S. Watson, and E. Saltzman, The Dominion Range ice core, Queen Maud Mountains, AntarcticaGeneral site and core characteristics with implications, J. Glaciol., 36, 11-16, 1990.

McKenzie, R. L., and P. V. Johnson, Springtime stratospheric $\mathrm{NO}_{2}$ in Antarctica, Geophys. Res. Lett., 11, 73, 1984.

Mumford, J. W., and D. A. Peel, Microparticles, marine salts and stable isotopes in a shallow core from the Antarctic Peninsula, Br. Antarct. Surv. Bull., 56, 37 47, 1982.

Shaw, G. E., On the residence time of the Antarctic ice sheet sulfate aerosol, J. Geophys. Res., 87, 43094313, 1982.

Toon, O. B., P. Hamill, R. P. Turco, and J. Pinto, Condensation of $\mathrm{HNO}_{3}$ and $\mathrm{HCl}$ in the winter polar stratospheres, Geophys. Res. Lett., 13, 1284-1287, 1986.

Turco, R. P., R. C. Whitten, and O. B. Toon, Stratospheric aerosols: Observations and theory, Rev. Geophys., 20, 233-2, 1982.

Watts, R. D., and W. Isherwood, Gravity surveys in glacier-covered regions, Geophysics, 43, 819-822, 1978.

Welch, K. A., P. A. Mayewski, and S. I. Whitlow, Methanesulfonic acid in coastal Antarctic snow related to the ice extent, Geophys. Res. Lett., 20, 443446, 1993. 
Wharton, R. A., Jr., C. P. McKay, G. D. Clow, D. T. Andersen, G. M. Simmons, Jr., and F. G. Love, Changes in ice cover thickness and lake level of Lake Hoare, Antarctica: Implications for local climate change, $J$. Geophys. Res., 97, 3503-3513, 1992.

Wilson, A. T., Evidence from chemical diffusion of a climatic change in the McMurdo dry valleys 1200 years ago, Nature, 201, 176-177, 1964.

J. Dibb, L. Fosberry, B. Lyons, P. A. Mayewski, M. Twickler, C. Wake, K. Welch, S. Whitlow, and G. Zielinski, Glacier Research Group, Institute for the Study of Earth, Oceans and Space, University of New Hampshire, Durham, NH 03824.
P. Grootes, Quaternary Isotope Laboratory, University of Washington, Seattle, WA 98195.

B. Lyons, Hydrology/Hydrogeology Program, Mackay School of Mines, University of Nevada, Reno, NV 895570138.

K. Taylor, Water Resources Center, Desert Research Institute, University and Community College System of Nevada, Reno, NV 89502.

P.-Y. Whung, Rosenstiel School of Marine and Atmospheric Sciences, University of Miami, Miami, FL 33149.
(Received March 1, 1993;

accepted September 17, 1993.) 